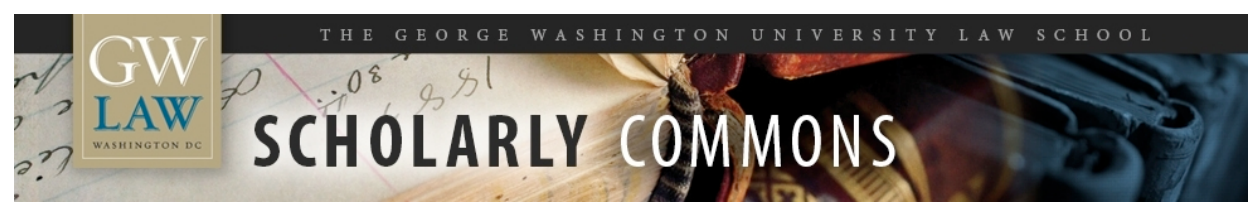

\title{
Properly Funding the Copyright Office: The Case for Significantly Differentiated Fees
}

Robert Brauneis

The George Washington University Law School, rbraun@law.gwu.edu

Follow this and additional works at: https://scholarship.law.gwu.edu/faculty_publications

Part of the Law Commons

\section{Recommended Citation}

Brauneis, Robert, Properly Funding the Copyright Office: The Case for Significantly Differentiated Fees (July 4, 2017). GWU Law School Public Law Research Paper No. 2017-58; GWU Legal Studies Research Paper No. 2017-58. Available at SSRN: https://ssrn.com/abstract=2997192

This Article is brought to you for free and open access by the Faculty Scholarship at Scholarly Commons. It has been accepted for inclusion in GW Law Faculty Publications \& Other Works by an authorized administrator of Scholarly Commons. For more information, please contact spagel@law.gwu.edu. 


\title{
PROPERLY FUNDING THE COPYRIGHT OFFICE: THE CASE FOR SIGNIFICANTLY DIFFERENTIATED FEES
}

\author{
Robert Brauneis*
}

Through its registration and recordation programs, the United States Copyright Office provides crucial information about the authorship, ownership, and copyright status of millions of works of authorship created over the last century. Peter Jaszi, to whom this Festschrift is dedicated, recognized this a quarter-century ago when he defended registration requirements as a member of the Library of Congress's Advisory Committee on Copyright Registration and Deposit: "the registration record provides a valuable database available to large and small participants in the copyright marketplace."1 However, the Copyright Office is seriously underfunded, compromising all of its functions, including registration and recordation. ${ }^{2}$ The essentially flat, front-end fees that the Office charges for registration and recordation fail to generate nearly enough revenue for the Office to survive, let alone thrive. Because the Office depends on Congress to appropriate taxpayer dollars to fund over a third of its budget, ${ }^{3}$ and

\footnotetext{
* Professor of Law and Co-Director of the Intellectual Property Law Program, The George Washington University Law School. For useful comments and important information, I would like to thank Steven Berk, Dmitry Karshtedt, and Zvi Rosen; for financial support, I would like to thank Dean Blake Morant; and for inspiration, I would like to thank Peter Jaszi, to whom this paper, as my contribution to Peter's Festschrift, is dedicated.

${ }^{1}$ Library of Congress Advisory Committee on Copyright Registration and Deposit, ACCORD: Report of the Co-Chairs, The Library of Congress Advisory Committee on Registration and Deposit, Robert Wedgeworth, Barbara Ringer, Co-Chairs (hereinafter "ACCORD Report," Appendix A/16 (1993); see id. Appendix A/85, A/86 (Jon Baumgarten \& Peter Jaszi, "Why Section 412 Should be Retained," Working Paper \#4a, July 12, 1993).

${ }^{2}$ As the Office itself has put it, it "has long operated on a shoestring budget." United States Copyright Office, Positioning the United States Copyright Office for the Future: Strategic Plan 2016-2020 (hereinafter "Copyright Office Strategic Plan," at 43 (December 1, 2015), available at https://www.copyright.gov/reports/strategic-plan/USCO-strategic.pdf.

${ }^{3}$ The exact percentage changes from year to year. The percentage also varies depending upon whether the Licensing Division, which administers compulsory licenses and is fully funded by fees, is included in calculations. So, for example, in Fiscal Year 2014, if the Licensing Division is included with the Copyright Royalty Judges and the remainder of the Copyright Office, fees provided 64.8\% of the Copyright Office Execution Plan budget; if the Licensing Division is not included, fees provided $62.2 \%$ of the budget. See Library of Congress Fiscal 2016 Budget Justification, at 7 .
} 
depends on its parent agency, the Library of Congress, to request those appropriations, it is chronically short of funds. As a result, the copyright information that the Copyright Office collects and provides is both significantly incomplete and terribly inconvenient to access, and the Office's other functions suffer as well.

The Copyright Office has traditionally opposed efforts to render it financially self-sufficient. Its principal worry has been that self-sufficiency would require sharply increased registration fees - "by at least a factor of five, from \$20 to the \$100 range," testified Register of Copyrights Marybeth Peters in $1996^{4}$ - which in turn would overburden copyright owners and lead to a steep decline in the use of the registration system. ${ }^{5}$ There is no reason, however, to treat the Copyright Office's current flat, front-end fee structure as sacrosanct. It could easily be considered puzzling, rather than obvious, why an applicant should pay the same amount in registration fees for a song that continues to generate substantial revenue 80 years after it was first published, and for a song that was never commercially successful, or to pay the same to register a motion picture with a budget of $\$ 200$ million and first week box office receipts of $\$ 220$ million, ${ }^{6}$ and to register a short story created by one person in a week.

Moreover, there is strong modern domestic precedent for significantly differentiated intellectual property fees, both across time and across different assets and applicants. Congress took significant steps towards differentiated fees for patents and trademarks in the 1980s, instituting "back-end" maintenance fees for utility patents in $1980,{ }^{7}$ creating small entity discounts for patent fees in

\footnotetext{
${ }^{4}$ Omnibus Patent Act of 1996; Hearing Before the Comm. on the Judiciary, Senate, 104th Cong., $2^{\text {nd }}$ Sess., Serial No. J-104-97, at 19 (1996) (statement of Marybeth Peters, Register of Copyrights). The Office of Management and Budget criticized Register Peters's estimate of a five-fold increase in fees, and she later came to the conclusion that, at least if the Copyright Office remained within the Library of Congress, fees would only have to be doubled. See United States General Accounting Office, Report to the Chairman, Committee on the Judiciary, U.S. Senate, Intellectual Property: Fees Are Not Always Commensurate With the Costs of Services 43-47 (criticizing Copyright Office cost projections), 49 (noting that Register Peters later stated that fees would have to double for the Office to become self-sustaining within the Library of Congress) (May 1997).

${ }_{6}^{5}$ See id.

6 I'm thinking of "Rogue One: A Star Wars Story," see http://www.thenumbers.com/movie/Rogue-One-A-Star-Wars-Story\#tab=summary, but of course similar figures could be cited for many movies.

${ }^{7}$ See P.L. 96-517, §2, 94 Stat. 3015 (December 12, 1980) (providing for maintenance fees due at three years and six months, seven years and six months, and eleven years and six months after issuance, for utility patents based on applications filed on or after December 12, 1980); id.
} 
$1982,{ }^{8}$ and increasing the frequency of trademark registration renewal from 20 years to 10 years in 1988. ${ }^{9}$ In 2012, the Leahy-Smith America Invents Act created further discounts for "micro entities." 10 As a result, a patent applicant can end up paying as little as $\$ 640$ and as much as $\$ 15,160$ for a simple issued patent $^{11}$ - a ratio of about 1:24 - depending on the applicant's size and on the desired patent duration. Although there is somewhat less differentiation in trademark fees, an applicant for a trademark registration currently pays between $\$ 225$ and $\$ 400$ for a single-class registration on the front end, but must also pay back-end fees, in the amount of $\$ 500$ per class every ten years, to maintain the registration. $^{12}$

That fee differentiation fulfills three important goals. First, it provides ample funds for optimal administration of the patent and trademark systems. The Patent and Trademark Office is entirely fee-funded, and has been since $1990 .{ }^{13}$ Those fees are sufficient to support its direct services to applicants, its nonservice activities that support the patent and trademark systems, and needed capital improvements. Moreover, the PTO's patent and trademark activities each stand on their own, since the PTO is prohibited by law from diverting funds from one to the other in either direction. ${ }^{14}$ Second, it goes some of the way towards spreading the cost of the patent and trademark systems according to the benefits received from them. Third, it increases affordability on the low end, making it possible to obtain patent rights for many relatively modest and unproven inventions, and to obtain the benefits of trademark registration for relatively modest and unproven brands.

\footnotetext{
${ }^{8}$ See P.L. 97-247, 96 Stat. 317 (Aug. 27, 1982).

${ }^{9}$ See Trademark Law Revision Act of 1988, P.L. 100-667, §§ 110-111, 102 Stat. 3935 (Nov. 16, 1988). This Act became effective one year after it was passed. See id. $\S 136$. Thus, registrations or renewals issued on or after November 16, 1989 last only for ten years, instead of the twenty years they had previously lasted.

${ }_{10}$ See Leahy-Smith America Invents Act, P.L. 112-29, 125 Stat. 316, § 10(b) (September 16, 2011) (codified at 35 U.S.C. $\$ 41$ note) (hereinafter "America Invents Act").

11 See United States Patent and Trademark Office, USPTO Fee Schedule, available at https://www.uspto.gov/learning-and-resources/fees-and-payment/uspto-fee-schedule (last visited November 20, 2016). $\$ 640$ is the sum of application, search, examination, and issuance fees for a micro entity; $\$ 15,160$ is the sum of those fees, plus maintenance fees, without any discount.

${ }^{12}$ See id.

${ }^{13}$ See Omnibus Budget Reconciliation Act, Public Law 101-508, § 10101, 104 Stat. 1388-1, 1388-391; Department of Commerce, Patent and Trademark Office, Study of Alternative Fee Structures, 65 Fed. Reg. 58746, 58747 (October 2, 2000).

${ }^{14}$ See 35 U.S.C. $\S \S 42(c)(3)(a), 42(c)(3)(B) ;$ America Invents Act, supra note 10, § 10(a)(2).
} 
In this article, I argue that the Copyright Office should follow the example of the Patent and Trademark Office, and charge significantly differentiated fees for registration and recordation. Just as patent and trademark fees are, those fees should be differentiated across time - over the life of a copyright - by splitting payment up into "front-end" fees imposed at the time of application, and "back-end" fees charged for renewal. They should also be differentiated across different works and applicants at the same time. In addition, I argue that the Copyright Office should be able to set fees based, not just on current costs of services rendered, but also on anticipated capital improvement costs, and on the cost of non-service activities that support the copyright system, such as the preparation of reports on copyright issues and the provision of public information about copyright law.

Whether differentiated copyright fees can provide ample funds for an entirely self-supporting Copyright Office is an open question, and it will need to remain open for some time. It is very unlikely that "front-end" fee differentiation alone could provide sufficient funding. As will be discussed further below, "back-end" renewal fees would and should probably only be imposed on new registrations, with the result that back-end revenue would not start flowing until those fees came due on new registrations. Thus, if the first requirement for renewal were fixed at ten years, as it is for trademark registrations, it would be ten years before the Copyright Office began to receive revenue from those fees. In the meantime, the Copyright Office would need to continue to rely on supplemental appropriations, and indeed, as the Office's most recent Technology Modernization Plan contemplates, ${ }^{15}$ would need increased appropriations for there to be any hope of remedying the deficiencies in its operations.

Although it would take years to fully implement differentiated fees, such fees would eventually produce a wide variety of benefits. They would enable the Copyright Office to better fulfill all of its missions; they would make registration and recordation more affordable for modest applicants and works, thus enlarging the stock of copyright information provided by the Copyright Office; and they would decrease or eliminate reliance on taxpayer support of the Office. Proposals for changing fee structures and for becoming self-funding have sometimes been linked to changes in the institutional status of the Office,

\footnotetext{
${ }^{15}$ See United States Copyright Office, Provisional Information Technology Modernization Plan and Cost Analysis, at 2 (February 29, 2016), available at https://www.copyright.gov/reports/itplan/technology-report.pdf.
} 
such as becoming part of a combined Intellectual Property Corporation, ${ }^{16}$ or becoming an independent agency. ${ }^{17}$ However, they need not be, and in this article, which takes no position on the Office's institutional status, they are not. Regardless of whether the Copyright Office remains part of the Library of Congress, fee and funding changes are important and would be helpful.

Part I describes some of the current deficiencies in Copyright Office operations, to acquaint the reader with the consequences of underfunding. Part II describes the Copyright Office's current fee structure, and contrasts it with the relatively recently developed differentiated fee structure of the Patent and Trademark Office. Part III explores how the Copyright Office could charge differentiated fees. It begins by outlining the treaty obligations that would place limitations on certain types of copyright fees. It then considers a variety of ways that the Office could differentiate fees, both across time and across different applicants and works, while remaining in compliance with treaty obligations. Lastly, it takes a first stab at considering whether differentiated fees could really generate enough additional revenue to make the Copyright Office self-sufficient, and whether that is a desirable goal. Part IV concludes.

\section{WHAT AN UNDERFUNDED COPYRIGHT OFFICE LOOKS LIKE}

The Copyright Office is quite aware of what it could and should be doing with respect to provision of copyright information. The second goal stated in its 2016-2020 Strategic Plan is to "[m]ake copyright records easily searchable and widely available to authors, entrepreneurs, and all who need them,"18 and as we will see, it has also articulated more specific objectives that make perfect sense. Yet the Office is also aware that has not had sufficient resources to accomplish those objectives, however far it has tried to stretch the resources it has had. Thus, its operations still have easily recognized deficiencies, as well as less easily recognized unfulfilled potential. Three areas of evident deficiencies involve document recordation, pre-1978 registration records, and post-1978 registration records.

\section{A. PAPER DOCUMENTS ONLY}

The Copyright Act designates the Copyright Office as the official public registry of documents that convey interests in works of authorship, such as

\footnotetext{
${ }^{16}$ See Omnibus Patent Act of 1996, S. 1961, 104th Cong, 2d Sess, (introduced July 2, 1996).

17 See Copyright Office for the Digital Economy Act, H.R. 4241, $114^{\text {th }}$ Cong., $1^{\text {st }}$ Sess. (introduced December 11, 2015).

${ }^{18}$ Copyright Office Strategic Plan, supra note 2, at 6.
} 
copyright assignments and licenses. ${ }^{19}$ The Copyright Office thus functions like an office of Recorder of Deeds does for real estate, but while Recorder of Deeds offices are local - their jurisdiction is usually limited to a single county - the Copyright Office serves as the only public registry in the United States for copyright documents. Surprisingly, the Copyright Office still only accepts paper documents for recording, just as it has since 1870, when it was not a separate office but merely a division of the Library of Congress, and the Library first assumed the function of a public registry of copyright documents. ${ }^{20}$ In this respect the Copyright Office is over a decade behind the Patent and Trademark Office (PTO), which launched its Electronic Trademark Assignment System in 2003, and its Electronic Patent Assignment System in 2004. ${ }^{21}$ It is also behind most local Recorders of Deeds offices in the United States, over 1500 of which have implemented electronic recording systems. ${ }^{22}$

A series of unfortunate consequences flow from the Copyright Office's failure to implement an electronic recording system. Paper-based recording is labor intensive. The Copyright Office uses about the same number of staff to process 11,000 documents per year as the PTO does to process 480,000 documents per year. ${ }^{23}$ The additional staff are needed principally because information from each paper document must be manually transcribed to create an electronic index. Manual transcription is so time consuming that even though the Copyright Office has a proportionally larger staff, in the years 2008-2012 there was an average delay of 225 days between submission of a submitted copyright document and its appearance in the electronic index on the Copyright Office's website, ${ }^{24}$ while electronically submitted patent documents typically appear on the PTO's website within a single day. ${ }^{25}$ Manual transcription is also expensive, which has led to the current charge of $\$ 105$ per document recorded, plus $\$ 35$ for each ten additional titles of works that are covered by the document. ${ }^{26}$ Such high charges undoubtedly reduce the number of documents

\footnotetext{
${ }^{19}$ See 17 U.S.C. § 205.

${ }^{20}$ See Robert Brauneis, Transforming Document Recordation at the Copyright Office 11 (2014) (hereinafter Transforming Document Recordation), available at http://copyright.gov/docs/recordation/recordation-report.pdf (last visited November 25, 2016).

${ }^{21}$ See id. at 56.

${ }^{22}$ See Property Records Industry Association, http://www.pria.us/ (home page, stating that 1570 recorders of deeds have implemented an electronic recording system) (last visited November 25, 2016).

${ }^{23}$ See Transforming Document Recordation, supra note 20, at 56.

${ }^{24}$ See id. at 35.

${ }^{25}$ See id. at 99.

${ }^{26}$ See United States Copyright Office, Circular 4: Copyright Office Fees (Rev. 11/2016), available at https://www.copyright.gov/circs/circ04.pdf.
} 
recorded. By contrast, since 2014, the PTO's fee for recording patent assignments electronically is zero. ${ }^{27}$ The Copyright Office badly needs an electronic recording system. ${ }^{28}$

\section{B. UNSEARCHABLE PRE-1978 REGISTRATIONS}

Until 1978, the Copyright Office's registration index was maintained entirely on paper. Almost 40 years later, the pre-1978 index is still only available on paper, which means that it cannot be searched electronically. That is unfortunate for at least two reasons. First, millions of works that gained federal copyright protection from 1923 onwards are still under copyright, yet official copyright information about those works, including their authors and owners, can only be gained through manual search of the approximately 12 million original registration records covering works registered from 1923 through $1977 .^{29}$ Second, millions of works that gained federal copyright protection from 1923 through 1963 are not under copyright, because no renewal registrations were filed for those works, as was then required to maintain copyright protection beyond an initial 28-year term. Only about 1.2 million renewal registrations were granted between 1950 and $1992,{ }^{30}$ leaving the vast majority of works that gained federal copyright protection after 1922 in the public domain. Although those works are in theory free to be used by anyone, many of them are not widely known to be available, because their public domain status can only be confirmed by a search of the Copyright Office's paper records. Efforts have been underway since 2010 to create an electronic index of pre-1978 records, and the Office's current strategic plan includes such an index as a performance objective. ${ }^{31}$ The Copyright Office has scanned about 37 million index cards, and is starting to transcribe information from those cards. ${ }^{32}$ However, those efforts are proceeding slowly, because only limited funds are

\footnotetext{
${ }^{27}$ See 78 Fed. Reg. 4212, 4240 (Jan. 18, 2013) (announcing the reduction of the fee for recording electronically to zero); USPTO Fee Schedule, supra note 11 (current fee for recording electronically is zero). The fee for recording a document submitted on paper is currently $\$ 40$. See id.

${ }^{28}$ Interestingly, the Copyright Office Strategic Plan does not speak specifically of a recording system that is capable of accepting documents electronically, but only of a "modern system for recording commercial and noncommercial copyright documents." See Copyright Office Strategic Plan, supra note 2, at 11.

${ }^{29}$ See Copyright Registrations and Renewals - 1870-2016 (Excel Spreadsheet compiled by Zvi Rosen, on file with author).

${ }^{30}$ See id.

${ }^{31}$ See Copyright Office Strategic Plan, supra note 2, at 18.

${ }^{32}$ Information about the digitization project is available on the Copyright Office's Digitization and Public Access page, https://www.copyright.gov/digitization/status.html.
} 
available. In its Fiscal Year 2010 budget request, the Library of Congress set a "key performance target" of having at least 10 million pre-1978 records online by September 30, 2010. ${ }^{33}$ Over six years after that deadline has passed, not a single pre-1978 record is online.

\section{Delay, Abridgment, And OMissions in Post-1978 Registrations}

Since 1978, the Copyright Office has maintained an electronic catalog of new registrations, which is now searchable online. The information available in that catalog, however, is of uneven quality. The Copyright Office began to cut back on the information it entered into catalog records in the 1990s. ${ }^{34}$ Those initial cutbacks, however, were not sufficient to keep cataloguing current. In the mid- to late-1990s, budget constraints led to staff reductions, which by the year 1999 resulted in a six- to eight-month backlog in examining and cataloging applications. ${ }^{35}$ In order to reduce the cataloging backlog, the Office further reduced the information added to each catalog record, using what were known as "trim orders," and for some periods dispensed with recording any information from the deposit copy submitted with the registration application, instead directing catalogers to enter information only from the application. ${ }^{36}$ The result is a large number of records in the electronic catalog that have very thin information, and that in some cases make it more difficult to identify the work that has been registered. Although the registration backlog was substantially reduced by the mid-2000s, it increased again in the late 2000 s, due in part to another wave of budget constraints and staff reductions. ${ }^{37}$

Since 2008, the Office has maintained an electronic registration system, which accepts registration applications online. Although this achievement is laudable, the system still has gaps. For example, in spite of the statutory mandate that applications for registration include "the name and nationality or

\footnotetext{
33 See Library of Congress Fiscal Year 2010 Budget Justification, p. 141, available at https://www.loc.gov/portals/static/about/reports-and-budgets/documents/budgets/fy2010.pdf.

${ }^{34}$ See Margaret Holley, Copyright Office Makes Final Decision on Catalog Record, available at http://www.guild2910.org/CopyrightCatalog.pdf.

${ }^{35}$ See Fiscal 2000 Budget Request, Statement of Marybeth Peters, The Register of Copyrights, before the Subcommittee on Legislative Branch, Committee on Appropriations, United States House of Representatives, 106th Congress, 1st Session (February 10, 1999) available at https://copyright.gov/docs/regstat 99. html.

${ }^{36}$ See id.

${ }^{37}$ See Annual Report of the Register of Copyrights, Fiscal Year Ending September 30, 2009, at 47 (2010), available at https://www.copyright.gov/reports/annual/2009/ar2009.pdf (noting that the average time for processing registrations rose from 81 days in 2007, to 163 days in 2008, to 309 days in 2009).
} 
domicile of the author or authors" of the works covered, ${ }^{38}$ the Copyright Office has established a practice of accepting some registration applications with radically incomplete authorship information. Authorship information is important. The basic term of copyright in a work is measured by the life of the author, ${ }^{39}$ so if we don't know who the author is, we have no way of figuring out whether the work is still under copyright. Moreover, authors are initial owners of copyright ${ }^{40}$ and generally have a non-waivable power to terminate transfers of copyright they have made, typically 35 to 40 years after the transfer in question. ${ }^{41}$ Thus, without knowing who the author of a work is, we don't know who might own copyright in that work if the registration claimant either did not properly obtain rights or obtained rights only for the purpose of registration, nor do we know who may be able to terminate any transfer that was made.

The practice of accepting incomplete authorship information began gathering steam in 1980, when the Copyright Office started to accept applications to register collective works and serials without complete authorship information, so long as a single entity owned copyright in all of their components. $^{42}$ In what was likely the typical case at the time, this practice may have seemed justifiable. A magazine publisher acquires copyright in a number of articles, each written by a different author, and publishes them in one issue of a magazine. The registration application lists only the publisher as author (of the collective work, because it selected and arranged the articles) and as claimant (as author of the collective work, and as assignee of copyright in the individual articles). Yet the published copies of the magazine themselves credit each author of each article, so there is a public record of authorship, even if it is not in the registration records, and the magazine publisher retains copyright in the articles, so the registration's identification of the claimant remains accurate for a long time.

More recently, however, applicants have started to use the registration system in ways that make the consequences of failing to provide authorship information much more serious. In a frequently litigated typical case, a stock photography agency acquires copyright in hundreds or thousands of photographs

\footnotetext{
3817 U.S.C. $\S 409(2)$.

39 See 17 U.S.C. $§ 302$ (a) (establishing a general copyright term of life of the author plus 70 years for works created on or after January 1, 1978).

${ }^{40}$ See 17 U.S.C. $\S 201$ (a).

${ }^{41}$ See 17 U.S.C. $§ 203$.

${ }^{42}$ See Alaska Stock, LLC v. Houghton Mifflin Harcourt Pub. Co., 747 F.3d 673, 679 (9th Cir. 2014) (quoting a declaration from the Associate Register for Registration and Recordation of the United States Copyright Office to that effect).
} 
taken by dozens of photographers, but only for the purpose of registration; copyright will revert to those photographers immediately after registration. ${ }^{43}$ The agency applies to register a single compilation or "automated database" that includes all of those photographs. It provides the names of only three of the photographers, and does not identify which photographs they have taken. The Copyright Office issues the registration, conferring all of the benefits of registration on the photographs, including the ability to file a lawsuit if any of them is infringed, and to obtain statutory damages and attorney's fees. However, the Office has not obtained any useful authorship or ownership information we don't know who took any of the photographs, nor who owns them once copyright reverts to their authors immediately after registration. Moreover, there is likely no other public record or authorship or ownership - few if any of the photos has been published with attribution or copyright notice, and even if they have, the registration doesn't say where they have been so published (unlike the registration for the magazine issue, which did). The result is that the copyright landscape becomes seeded with landmines - works the use of which can be punished with statutory damages and attorney's fees, but about which there is no useful record of authorship, ownership, or copyright status.

Why have courts validated this Copyright Office practice? An important factor is the Copyright Office's limited budget. As a 2014 Ninth Circuit decision noted, before the introduction of electronic registration in 2008, a practical argument for accepting limited authorship information was "the expensive and error-prone tedium of the Copyright Office typing all the names [of authors] into its records." 44 Even now that electronic registration has been introduced, "questions remain about the capacity of the system to accommodate applications listing very large numbers of authors or titles." 45 In short, the limited resources of the Copyright Office have become an excuse not to provide essential

\footnotetext{
${ }^{43}$ For cases that present variations on these facts, see Alaska Stock, LLC, 747 F.3d at 673-675; Metropolitan Regional Information Systems, Inc. v. American Home Realty Network, Inc., 722 F.3d 591, 596-600 ( ${ }^{\text {th }}$ Cir. 2013); Muench Photography, Inc. v. Houghton Mifflin Harcourt Pub. Co., 712 F.Supp.2d 84 (S.D.N.Y. 2010); Muench Photography, Inc. v. Pearson Education, Inc., 2013 WL 6185200 at *10 (N.D. Cal. November 19, 2013); Pacific Stock, Inc. v. Pearson Education, Inc., 2012 WL 93182, *4-*5 (D. Haw. January 11, 2012); Panoramic Stock Images, Ltd. v. John Wiley \& Sons, Inc., 2014 WL 4344095, at *8 (N.D. Ill. September 2, 2014).

${ }^{44}$ Alaska Stock, LLC v. Houghton Mifflin Harcourt Pub. Co., 747 F.3d 673, 681 (9th Cir. 2014).

${ }^{45} \mathrm{Id}$. at 682.
} 
information about who created the works that are granted the benefits of registration. $^{46}$

\section{UNFULFILLED POTENTIAL}

So far, I have described three of the Copyright Office's most obvious deficiencies in collecting and providing copyright information. But there is much more that the Copyright Office could do to better perform those functions. For example, it could provide an application programming interface to the Copyright Office Electronic Catalog, the Office's electronic catalog of copyright registrations, recorded documents, and other transactions, so that any software developer who wanted to could build applications that would integrate current copyright information. ${ }^{47}$ Music streaming services such as Spotify and Pandora could provide information about the copyright of the songs they play. Image search engines such as Google Images and TinEye could provide copyright information about images. Google Books could provide copyright information about books; IMDB about movies; and so on. Independent software developers could also improve on the cumbersome, limited web search capabilities for the Catalog provided by the Copyright Office. ${ }^{48}$ The result would be more readily available copyright information, and increased awareness of copyright and of the availability of copyright registration.

The Copyright Office could also work with the developers of authoring software - image editing software such as Adobe Photoshop or GIMP, video editing software such as Avid Media Composer or Adobe Premiere Pro, audio software such as ProTools or Audacity, text editing software such as Microsoft Word - to link directly to online copyright registration from the software: done with your work? Register it! By making the opportunity to register more conspicuous, and the registration process easier, the Office could increase the

\footnotetext{
${ }^{46}$ To its credit, the Copyright Office is trying to discourage the practice of registering large groups of photographs as automated databases. It is proposing to adopt a narrow definition of "automated database," under which only databases that are accessible solely through a search tool would count as automated databases. See Registration of Group Photographs, Notice of Proposed Rulemaking, 81 Fed. Reg. 86643, 86654 (December 1, 2016). It also cautions that registration of a group of photographs as a compilation may mean that only one award of statutory damages is available for the entire compilation, no matter how many individual items are infringed. See id.

${ }^{47}$ See Copyright Office Strategic Plan, supra note 2, at 18 (one of the performance objectives in the Copyright Office's Strategic Plan is that "business-to-business services offered by the Office will share data and connect public and private copyright records").

${ }^{48}$ See http://cocatalog.loc.gov/.
} 
number of works registered and therefore the reach of its catalog of works under copyright. $^{49}$

\section{Fee Structures, Allowable Cost Recovery, and Reserve AUTHORITIES: CONTRASTING THE COPYRIGHT OFFICE WITH THE PATENT AND TRADEMARK OFFICE}

Current Copyright Office fees differ from Patent and Trademark Office fees in four important ways: the timing of the fees; the variation in rates for different applicants; the costs the fees are allowed to cover; and the agency's ability to hold those fees in a reserve fund.

\section{A. FRONT- AND BACK-END FEES}

First and most strikingly, the Copyright Office fees are all "front-end" they are single charges at the time of service. By contrast, the Patent and Trademark Office assesses significant "back-end" fees - in the case of patents, maintenance fees at 3.5, 7.5 and 11.5 years after the date of issue, ${ }^{50}$ and in the case of trademarks, renewal fees every 10 years after registration. ${ }^{51}$ The PTO pursues a conscious policy of setting "front-end" fees below cost, and "backend" fees above cost. For example, the utility patent search and examination fees are set at $\$ 600$ and $\$ 720$ respectively (without further discounts for small and micro entities); ${ }^{52}$ the estimated average cost for those activities is, as of Fiscal Year 2015, \$1773 and \$2205, respectively. ${ }^{53}$ The large-entity fee for issuance of a granted patent, however, is $\$ 960,{ }^{54}$ well above the FY 2015 estimated unit cost of $\$ 314,{ }^{55}$ and the maintenance fees $-\$ 1600$ due at 3.5 years

\footnotetext{
${ }^{49}$ Other suggestions include allowing independent registrars to offer registration services, as is the current practice with domain names. See Pamela Samuelson \& Members of the Copyright Principles Project, The Copyright Principles Project: Directions for Reform, 25 Berkeley Tech. L. J. 1175, 1203-1204 (2010), available at http://scholarship.law.berkeley.edu/facpubs/563. Independent registrars, including trade associations, would no doubt find alternative methods of promoting registration, and likely increase the number of registrations substantially. Providing independent registrars access to back-end registration processes or the official database (catalog) of registrations, however, would also require a much more complicated and secure system.

${ }^{50}$ See 35 U.S.C. $\S 41(b)$.

${ }^{51}$ See 15 U.S.C. $\$ 1059$.

${ }^{52}$ See USPTO Fee Schedule, supra note 11.

${ }^{53}$ See United States Patent and Trademark Office, Table of Patent Fees - Current, Proposed and Unit Cost, available https://www.uspto.gov/sites/default/files/documents/Table\%20of\%20Patent\%20Fees\%20$\% 20$ Current, \%20Proposed\%20and\%20Unit\%20Cost.pdf.

${ }^{54}$ See USPTO Fee Schedule, supra note 11.

${ }^{55}$ See id.
} 
after issuance, $\$ 3600$ due at 7.5 years, and $\$ 7400$ due at 11.5 years ${ }^{56}$ - have only a minimal cost of collection. This has been a conscious policy at the PTO for over 30 years. As the PTO stated in a recent notice proposing a new fee schedule,

Many of the initial filing fees are intentionally set below unit cost in order to foster innovation by removing barriers to entry for innovators. To balance the aggregate revenue loss of fees set below cost, other fees must be set above cost in areas where it is less likely to reduce inventorship (e.g., maintenance) ${ }^{57}$

The combination of lower front-end fees and higher back-end fees doesn't just foster innovation; it also likely maximizes PTO revenue. Demand for front-end services is almost certainly more price-sensitive, or elastic, and hence an increase in front-end fees would result in a greater decrease in applications, thus decreasing revenue. The back-end fees generate a very substantial portion of total PTO revenue; in Fiscal Year 2016, 42.5\% of all patent revenue came from maintenance fees. ${ }^{58}$ Without that revenue, the PTO would be utterly unable to maintain its patent operations.

The skew towards back-end fees is not quite as dramatic for trademarks, but it is still significant. The current initial full-price fee for registering electronically a trademark for a single class of goods or services $-\$ 400^{59}-$ is somewhat less than the PTO's estimated average cost of examination and issuance - $\$ 473$ in Fiscal Year 2015. ${ }^{60}$ The fee for renewal every ten years $\$ 300$ when submitted electronically ${ }^{61}$ - is almost ten times the \$31 FY 2015

\footnotetext{
${ }^{56}$ See USPTO Fee Schedule, supra note 11.

${ }^{57}$ United States Patent and Trademark Office, Setting and Adjusting Patent Fees During Fiscal Year 2017 (hereinafter "Setting and Adjusting FY2017 Patent Fees"), 81 Fed. Reg. 68150, 68159-68160 (October 3, 2016); see id. at 68177 ("Both the current and proposed fee schedules are structured to collect more fees at the back-end (i.e. issue fees and maintenance fees), where the patent owner has the best information about a patent's value, rather than at the front-end (i.e. filing fees, search fees, and examination fees), when applicants are most uncertain about the value of their art, even though the front-end services are costlier to the Office.").

${ }^{58}$ See United States Patent and Trademark Office, Performance and Accountability Report Fiscal Year 2016 (hereinafter "PTO FY2016 Report"), at 40, available at https://www.uspto.gov/sites/default/files/documents/USPTOFY16PAR.pdf.

59 See United States Patent and Trademark Office, Trademark Application Fee Structure, https://www.uspto.gov/trademarks-application-process/filing-online/trademark-applicationfee-structure.

${ }^{60}$ See United States Patent and Trademark Office, USPTO Trademark Fee Adjustment Table of Trademark Fees - Current, Final Rule, and Unit Cost (hereinafter "Table of Trademark Fees"), https://www.uspto.gov/sites/default/files/documents/Table\%20of\%20Trademark\%20Fees\%20$\% 20$ Current $\% 2$ C\%20Final\%20Rule\%20and\%20Unit\%20Cost\%20082516.pdf

${ }^{61}$ See USPTO Fee Schedule, supra note 11.
} 
average cost to the PTO of processing that renewal. ${ }^{62}$ Although only about $9 \%$ of the trademark revenue of the PTO comes from renewals proper, about $24 \%$ of its revenue comes from what it calls fees for "maintaining exclusive rights," which include renewal fees, fees for filing affidavits of use under Section 8 of the Lanham Act (which must be filed within the fifth and sixth year of registration to maintain that registration), fees for filing "incontestability" affidavits under Section 15, and other related fees. ${ }^{63}$

\section{B. VARIATION IN RATES FOR DIFFERENT APPLICANTS}

The Copyright Act would seem to grant the Copyright Office significant power to vary fees charged to different applicants for similar services. While $\S$ 708(b)(2) provides that fees shall be set at rates "not more than that necessary to cover the reasonable costs incurred by the Copyright Office for [registration, recordation, and other] services," 64 that limitation is best read to operate on the aggregate level, and not to require that the fee charged to each applicant be no larger than the costs of providing services to that applicant. In confirmation of the Copyright Office's power to vary fees by type of work and applicant, $\S$ 708(b)(4) provides that "fees established under this subsection shall be fair and equitable and give due consideration to the objectives of the copyright system." 65 In 2014, the Copyright Office introduced a \$35 fee for "single" copyright registrations (single work, single author/claimant), discounted from the standard rate of $\$ 55$, after considering the objectives of the copyright system. As it said in explaining its introduction of the fee, "[t]he Office understands that works of independent creators fuel the nation's economy and are critical to the Library of Congress' collections. Moreover, if individual authors do not register and are not part of the public database, they - more than any other group of copyright owners - may be difficult to find." 66 The Office has also provided for certain types of group registrations, which can be viewed as discounts for included works. However, it has made relatively little use of its authority to vary fees. There is more variation in patent fees; as noted above, the Patent Act itself

\footnotetext{
${ }^{62}$ See Table of Trademark Fees, supra note 60.

${ }^{63}$ See Trademark Fee Adjustment Aggregate Revenue Estimates: NPRM Proposal, available at https://www.uspto.gov/sites/default/files/documents/Aggregate\%20Revenue\%20Table\%20for \%20Proposed\%20Trademark\%20Fees.pdf (estimated total collections of the USPTO in FY2017 are $\$ 325,869,200$; estimated collections from renewal fees, including both electronic and paperbased, and including late fees and correction fees, are $\$ 28,538,596$; estimated collections for all fees for maintaining exclusive rights are $\$ 78,857,663$

${ }^{64} 17$ U.S.C. $\$ 708(b)(2)$.

${ }^{65} 17$ U.S.C. $\$ 708(b)(4)$.

${ }^{66}$ United States Copyright Office, Proposed Schedule and Analysis of Copyright Fees to Go Into Effect On or About April 1, 2014, at 17 (1993) (hereinafter "2014 Fee Study").
} 
provides for $50 \%$ discounts for certain fees for "small" entities, and 75\% discounts for "micro" entities. ${ }^{67}$ There are discounts for filing trademark applications in a way that simplifies their processing by the PTO - so-called "TEAS Plus" and "TEAS Reduced Fee" applications ${ }^{68}$ - but trademark registration fees are not otherwise discounted by entity type.

\section{RECOVERING THE Cost OF NON-SERVICE ACTIVITIES AND CAPITAL IMPROVEMENTS}

The Copyright Office cannot set registration and recordation fees which "together generat[e] well over $90 \%$ percent of the Office's fee receipts" 69 - any higher than is necessary to cover the cost, in the aggregate, of those services. As noted above, § 708(b)(2) of the Copyright Act empowers the Office to adjust registration and recordation fees "to not more than that necessary to cover the reasonable costs incurred by the Copyright Office for [those] services." ${ }^{70}$ As a result, the Office cannot raise revenue to cover the cost of performing its other statutory functions, which are important to maintaining the copyright system but are not directly related to client services. ${ }^{71}$ These include advising Congress, other federal agencies, and the courts on copyright law; participating in international meetings; conducting studies on various aspects of

${ }^{67}$ See America Invents Act, supra note $10, \S 10(\mathrm{~b})$.

68 See United States Patent and Trademark Office, "Initial Application Forms," https://www.uspto.gov/trademarks-application-process/filing-online/initial-applicationforms\#plus.

692014 Fee Study, supra note 66, at 12.

7017 U.S.C. $\$ 708(\mathrm{~b})(2)$.

${ }^{71}$ See id. ("[A]s in earlier studies, this most recent study continued to exclude costs associated with the policy and international programs, the mandatory deposit program, and programs dedicated to providing general education and information to the public"). The Copyright Office could be a little more transparent about its budget than it is. The 2014 Fee Study document does not provide any detail about how the Office allocated costs between its fee-generating and nonfee-generating activities. Likewise, Copyright Office Annual Reports do not provide any breakdown of expenditures and costs. I filed a FOIA request to try to get some additional detail. The Copyright Office eventually produced a document that provided figures for expenditures by department for the past five fiscal years. See United States Copyright Office Budget Documents, https://www.muckrock.com/foi/united-states-of-america-10/united-states-copyright-officebudget-documents-31449/ (Muckrock web page displaying my request and the Copyright Office's response). However, even that document leaves large swathes of costs unallocated. First, some departments, such as the Copyright Technology Office, provide services to other Copyright Office departments, and those costs are not allocated to those other departments. Second, and more fundamentally, every Copyright Office budget has a very large figure for "Non Pay / Overhead Accounts," which ranges from \$6.9 million to \$9.6 million of a total budget of $\$ 43.6$ to $\$ 51.9$ million - a "black box" figure for 15 to 20 percent of the entire budget. 
copyright law; conducting educational programs; and conducting DMCA exemption rulemakings. ${ }^{72}$

By contrast, the Patent and Trademark Office is empowered to set fees adequate to "recover the aggregate estimated costs to the Office for processing, activities, services, and materials relating to patents (in the case of patent fees) and trademarks (in the case of trademark fees)."73 The words "activities" and "materials" are the crucial ones. They enable the PTO to set fees adequate to cover, not just the cost of its services to patent and trademark applicants and holders, but the cost of everything it does to support the patent and trademark systems, including all of its advisory, research, and educational activities that are not directly related to providing patent and trademark services.

The authority to charge fees that in the aggregate cover more than the cost of services provided may be somewhat illusory when considered only in relationship to front-end fees. As noted above, the PTO typically sets front-end fees below cost, and so it doesn't matter that they could be set above cost. The Copyright Office also sets its front-end fees below cost. For example, the Office estimated that by implementing its proposed 2014 registration fees, it "would recover $71 \%$ of the costs of processing electronic claims and $66 \%$ of the costs of processing paper applications." 74 It is only by imposing above-cost back-end fees that the PTO covers, not only the full cost of its services, but the cost of its other activities in support of the patent and trademark systems.

Former Register of Copyrights Maria Pallante has been among those who have stated that the Copyright Office does not have the authority to set fees based on the cost of capital improvements. ${ }^{75}$ It is not quite clear whether this is so. As noted, the Copyright Office has the power to recover the cost of providing services, and arguably the cost of providing services should include the cost of making needed improvements to the infrastructure required to provide those services. Surely the Office should not be doomed to paper-based processing because "cost" does not include the cost of implementing electronic processing, suitably amortized. However, any such limitation would also currently seem to be merely theoretical, because the Copyright Office sets most fees at below even their current operational cost, let alone the cost of making capital improvements.

\footnotetext{
72 See 17 U.S.C. § 701(b); 17 U.S.C. § 1201(a)(1)(C).

${ }^{73}$ Leahy-Smith America Invents Act, P.L. 112-29, 125 Stat. 316, § 10(a)(2) (September 16, 2011) (codified at 35 U.S.C. $\S 41$ note).

${ }^{74} 2014$ Fee Study, supra note 69, at 16.

${ }^{75}$ See, e.g., Maria A. Pallante, The Twenty-First Century Copyright Office, 61 J. Copyright Soc'y 213, 232 (2014)
} 


\section{RESERVE ACCOUNTS}

The Copyright Office does not in practice have the ability to build a reserve account across budget cycles, which would give it additional stability needed to continuously provide services and to invest in capital improvements given fluctuations in receipts and appropriations. In theory, $\S 708(\mathrm{~d})$ the Copyright Act provides that the fees collected by the Copyright Office "shall remain available until expended." However, Congress has routinely required the Office to offset its appropriations request by whatever reserve income it has accumulated by the end of a fiscal year, thus emptying any potential reserve fund. By contrast, the Patent and Trademark Office, which also has authority to build reserves, ${ }^{76}$ has actually been able to do so. As a result, it was able to continue to provide services during the federal government shutdown in fall $2013,{ }^{77}$ while the Copyright Office had to close ${ }^{78}$ thus halting some copyright litigation and transactions due to the inability to procure registrations and record documents. The PTO has also noted that its reserve fund has enabled it "to maintain progress on IT investments when patent filings (and subsequently revenue) decreased in FY 2015." "79 The PTO's practical ability to maintain a reserve fund is pretty clearly tied to its status as a fully fee-funded agency; the Copyright Office's dependence on appropriations weakens it considerably.

\section{A Fully-Funded, DifFERENTIAL FEE Copyright OFFICE: OPPORTUNITIES AND OBSTACLES}

By adopting differential fees, could the Copyright Office generate sufficient revenues to fully and amply fund itself, without adverse side effects such as decreases in registrations and recorded documents? The Copyright Office has been receiving about \$20-25 million per year in general appropriations support, ${ }^{80}$ so a target figure for additional revenue might be $\$ 35$

\footnotetext{
${ }^{76}$ See 35 U.S.C. $\$ 42(\mathrm{c})(2)$.

${ }^{77}$ See Setting and Adjusting FY2017 Patent Fees, supra note 57, at 68152.

78 See https://www.copyright.gov/eco/notice_special.html (notifying the public that the Copyright Office is closed as of 12:01 a.m. on October 1, 2013 due to the federal government shutdown).

${ }^{79}$ See Setting and Adjusting FY2017 Patent Fees, supra note 57, at 68152.

${ }^{80}$ See Library of Congress Fiscal Year 2017 Budget Justification, at 99, available at https://www.loc.gov/portals/static/about/reports-and-budgets/documents/budgets/fy2017.pdf (the Fiscal Year 2016 Operating Plan included appropriations above and beyond collections of \$23.1 million); Library of Congress Fiscal Year 2016 Budget Justification, at 99, available at https://www.loc.gov/portals/static/about/reports-and-budgets/documents/budgets/fy2016.pdf (the Fiscal Year 2015 Operating Plan included appropriations above and beyond collections of \$20.72 million); Library of Congress Fiscal Year 2015 Budget Justification, at 99, available at https://www.loc.gov/portals/static/about/reports-and-budgets/documents/budgets/fy2015.pdf
} 
million per year, although, as detailed below, additional funds are initially needed to catch up after decades of underfunding. Although I am optimistic that the Copyright Office could become self-sufficient, I concede that the matter is not entirely clear. However, differential fees would need to be introduced gradually in any event, and the Copyright Office could gather additional information about the effect of fee changes as it began to introduce them. Moreover, whether or not the Copyright Office could do away with support from appropriated funds altogether, it could certainly greatly reduce its reliance on them, and that is a worthy goal in itself. This section will begin by considering the treaty obligations that set outside limits on the types of additional fees that could be created. It then considers two types of fee differentiation - across time and across claimants and works - that could be introduced, and considers economic and legal issues with regard to variations of each. Finally, it considers the advantages and disadvantages of the goal of self-sufficiency.

\section{A. The OUter Limits: TREATy OBLigations}

Many readers of this paper will have already wondered whether the obligations of the United States under the Berne Convention and the TRIPS Agreement would limit the ability of the Copyright Office to impose new fees. Although they do set some limitations, they should not stand in the way of many effective fees. Article 5(2) of the Berne Convention, which is incorporated into TRIPS, famously provides that "[t]he enjoyment and the exercise of [the] rights [guaranteed by the Convention] shall not be subject to any formality." 81 Registration and recordation certainly count as formalities. The Berne Convention limitations generally apply only to works outside of their country of origin, ${ }^{82}$ and thus Congress could impose any fees it wanted to on domestic works. In fact, only domestic works are subject to the Copyright Act's requirement of registration as a condition for filing an infringement suit, ${ }^{83}$ precisely because the Berne Convention prohibition on formalities does not apply to them.

Understandably, there may be little political will to impose new formalities on domestic works alone. Yet Article 5(2) leaves substantial leeway

(the Fiscal Year 2015 Operating Plan included appropriations above and beyond collections of \$17.03 million).

${ }^{81}$ Berne Convention (Paris Act) Art. 5(2).

${ }^{82}$ See Berne Convention (Paris Act) Art. 5(1) (providing that authors shall enjoy certain rights in respect to works "in countries of the Union other than the country of origin"). For an exception, see $i d$. Art 5(3) ("[W]hen the author is not a national of the country of origin of the work for which he is protected under this Convention, he shall enjoy in that country the same rights as national authors.").

${ }^{83}$ See 17 U.S.C. $\S 411$. 
with regard to registration requirements for foreign works as well. Most importantly, the United States has always interpreted the Berne Convention not to require the provision of the extraordinary remedies of statutory damages and attorney's fees. Thus, even after joining the Berne Convention, it has continued to require all works, domestic and foreign, to be registered before the commencement of infringement (with a grace period after publication) as a condition of obtaining those remedies. ${ }^{84}$ That likely provides a far broader incentive to register than the requirement of registration before infringement litigation. And in that regard, copyright registration is quite similar to federal trademark registration: both provide additional protection, but neither is necessary for basic recognition of copyright and trademark rights respectively. As noted above, federal trademark registration is subject to renewal, and copyright registration could be as well; the availability of statutory damages and attorneys' fees upon infringement could lapse if a copyright owner decided not to renew its registration for a work.

In addition, the basic term of copyright guaranteed by the Berne Convention is only the life of the author plus fifty years, while the basic term of copyright in the United States is twenty years longer. This has led some, including former Register of Copyrights Maria Pallante, to argue that the United States could impose a renewal requirement, or a maintenance fee similar to those imposed on patents, as a condition of extending copyright protection for the last twenty years of the maximum term. ${ }^{85}$

\section{B. FeE DifFEREnTIATION ACROSS Time: Renewal FEeS}

Creation of a requirement to renew copyright registrations is attractive for a number of reasons. First, it allows registrants to test whether a work will be economically successful before deciding whether spend more to secure enhanced protection for it for a longer time. Second, while generating more revenue for the Copyright Office, renewal registration also increases the quality of copyright information. When renewing, applicants will provide updated information about the identity and contact details of the copyright owner. Third, as long as the failure to renew leads only to the loss of the additional remedies of statutory damages and attorneys' fees (and perhaps to the loss of the presumption that the owner on the original registration certificate remains the

${ }^{84}$ See 17 U.S.C. $\$ 412(a)$.

${ }^{85}$ See Maria A. Pallante, The Next Great Copyright Act, 36 Colum. J. Law \& Arts 315, 336-337 (2013). 
owner of the work), the imposition of a renewal requirement should not violate the United States's treaty obligations. ${ }^{86}$

For a generation of attorneys and scholars who fought to eliminate formalities in U.S. copyright law and promote U.S. accession to the Berne Convention, ${ }^{87}$ the prospect of a renewal requirement of any kind will generate reflexive opposition. More specifically, some will fear that a renewal requirement could be a "trap for the unwary," 88 even if the consequences of failure to renew would only be loss of enhanced remedies and factual presumptions, rather than loss of copyright protection altogether. Yet those fears can be addressed in part by precautions adopted for patent and trademark renewals, such as the provision of a six-month grace period for renewal even after the deadline has passed. ${ }^{89}$

\footnotetext{
${ }^{86}$ The Patent and Trademark Office has acknowledged that one of the functions of maintenance fees is to shorten the term of some patents: "The Office also recognizes that the lower maintenance fee rates would likely lead to increased renewal rates. Patents that are maintained beyond their useful life could weaken the IP system by slowing the rate of public accessibility and follow-on inventions, which is contrary to the Office's policy factor of fostering innovation." United States Patent and Trademark Office, Regulatory Impact Analysis: Setting and Adjusting Patent Fees During Fiscal Year 2017 In Accordance With Section 10 of the Leahy-Smith America Invents Act, Proposed Rule, at 58, available at https://www.uspto.gov/sites/default/files/documents/Regulatory\%20Impact\%20Analysis.docx Similarly, Congress has recognized curtailment of trademark rights, or apparent trademark rights, as one of the goals of increasing the frequency of trademark registration renewal from 20 years to 10 years. See Trademark Law Revision Act of 1988, Sen. Rep. 100-515, 100 $0^{\text {th }}$ Cong., $2^{\text {nd }}$ Sess. 6 ("[The Act] confronts the problem posed by the volume of abandoned or inactive marks ("deadwood") on the Federal Register in three ways."). While a renewal requirement for copyright registrations would affect neither the term nor the scope of copyright protection, it would limit available remedies, and thus could reduce the problem caused by orphan works. See, e.g., Shawn Bentley Orphan Works Act, S. 2913, 100 ${ }^{\text {th }}$ Cong., 2d Sess. (introduced September 27, 2008) (limiting the remedies in a civil action brought for infringement of copyright in an orphan work)

87 See, e.g., Irwin Karp, A Future Without Formalities, 13 Cardozo Arts \& Ent. L.J. 521 (1995); Arthur Levine, The End of Formalities: No More Second-Class Copyright Owners, 13 Cardozo Arts \& Ent. L.J. 553 (1995); Shira Perlmutter, Freeing Copyright From Formalities, 13 Cardozo Arts \& Ent. L.J. 565 (1995).

${ }^{88}$ See, e.g., United States Copyright Office, Report on Orphan Works, at 3 (2006), available at https://www.copyright.gov/orphan/orphan-report-full.pdf ("[T]here was substantial evidence presented during consideration of the 1976 Act that the formalities such as renewal and notice, when combined with drastic penalties like forfeiture of copyright, served as a 'trap for the unwary' and caused the loss of many valuable copyrights.").

${ }^{89}$ See 15 U.S.C. § 1059(a) (providing for a six-month grace period for trademark renewals); 35 U.S.C. § 41(b)(2) (providing for a six-month grace period for patent maintenance fee payments); see also 35 U.S.C. § 41(c) (authorizing the PTO to accept a maintenance fee payment made after the end of the grace period if the delay is shown to have been unintentional).
} 
How much revenue a renewal registration requirement could generate depends in part upon its timing. Over the past 25 years, the number of registrations received annually by the Copyright Office has stayed close to the range of 500,000 to 600,000. Under the Copyright Act of 1909, renewal was required in the twenty-eighth year of copyright, which is a relatively long time after originally obtaining protection. The average renewal rate for all works registered from 1909 through 1963 is about $14 \% .^{90}$ If $14 \%$ of 500,000 registrations were renewed every year, that would only be 70,000 renewals (assuming a one-time renewal requirement), which at a renewal fee of $\$ 100$ would generate only $\$ 7$ million. Fourteen percent may be too low an estimated renewal rate, however, because the renewal rate increased fairly steadily from 1937 (for works originally registered in 1909) to 1991 (for works originally registered in 1963). By 1991, the last year of the renewal requirement, about $21 \%$ of registrations were being renewed. ${ }^{91}$ A $21 \%$ rate of renewal of 500,000 renewals at $\$ 100$ would bring in $\$ 10.5$ million.

An alternative would be the trademark model of requiring multiple renewals at some specified interval - in the case of current trademark law, every 10 years. First renewal rates for trademarks - renewals made ten years after initial registration - have been running in the range of $28 \%-33 \%,{ }^{92}$ and rates for second renewals, made 20 years after registration, in the range of $22 \%$ $27 \% .^{93}$ Thus, for example, if in the year 2037 copyright registrants were renewing registrations originally made in 2017 and 2027, and if there were 500,000 registrations in each of those years, a 30\% renewal rate for 2027 registrations and a $25 \%$ renewal rate for 2017 registrations at a $\$ 100$ renewal fee would generate $\$ 27.5$ million in revenue. Of course, there is no reason to think that copyright registrations would be renewed at the same rates as trademark registrations, but the fact that copyrights were renewed at a rate of $21 \%$ after 28 years in $1991^{94}$ suggests that 10- and 20-year renewals would likely be higher than $21 \%$.

One drawback of creating a renewal registration requirement is the likely delay between creation and first receipt of fees. When Congress introduced maintenance fees for patents and increased the frequency of trademark renewals from 20 years to 10 years, it did so only prospectively. Thus, the PTO did not

\footnotetext{
${ }^{90}$ Zvi Rosen, Copyright Registrations and Renewals (Excel worksheet, on file with author).

${ }^{91}$ See Copyright Registrations and Renewals, supra note 90.

92 These figures are based on a chart of renewal numbers and rates from Fiscal Year 2003 through Fiscal Year 2016 kindly provided by Steven Berk, Trademarks Chief of Staff at the U.S. Patent and Trademark Office. I have made the chart available at http://www.robertbrauneis.net/cofunding/TrademarkRenewalChart.pdf.

${ }^{93}$ See supra note 92.

${ }^{94}$ See Copyright Registrations and Renewals, supra note 90.
} 
receive its first patent maintenance fees until three-and-a-half years after they were created, and did not receive a full complement of first-, second-, and thirdperiod maintenance fees until eleven-and-half years after they were created. Similarly, the PTO did not see its first set of ten-year trademark renewal fees until ten years after they were created. Whether or not Congress could constitutionally impose a renewal requirement on copyright registrations that it had already granted, one could imagine that the political opposition to doing so would be even greater than the opposition to renewal fees generally. Thus, a 10year renewal requirement, created in 2017, would not start to produce fees until 2027. That would give copyright owners a great deal of time to get used to the idea of paying renewal fees, but it would also substantially postpone Copyright Office benefit from those fees.

Legislation would be needed to create renewal requirements for registrations; as far as I can tell, the Copyright Office's current authority to set registration fees does not encompass the power to limit the term of registrations or to create a requirement to renew them.

\section{FeE DifFEREnTiation Across ApPlicAnts AND Works}

The Copyright Office should also consider charging different fees to different applicants, and for different works. As noted above, the Office currently does offer a modest discount for a "single application" - \$35 instead of $\$ 55$ - which can only be filed by individual claimants who are also authors, and which is therefore in essence similar to the "micro entity" discount of the Patent and Trademark Office. ${ }^{95}$ Without offering details, the Copyright Office's Strategic Plan proposes additional differentiation by entity size. ${ }^{96}$ Yet there is a limit to the scale of differentiation on the basis of entity size alone, and $4: 1$, the difference between large entity and micro entity fees for many patent services, may be close to that limit. The problem is that the value of or investment in a particular invention or work of authorship may not correspond to the size of the entity that is applying to register it. True, large entities may be less sensitive to service prices for other reasons - they may be more easily able to raise or borrow money to bridge the time between paying up-front fees and earning revenue from their investments, and they may have larger portfolios of inventions or works of authorship that spread the risk of failure and the rewards of gain. Yet large entities also file more registration applications, magnifying any fee hike. For example, a search of the Copyright Office's online registration database reveals

\footnotetext{
${ }^{95}$ See supra TAN 5-8 (noting small entity and micro entity discounts for patent fees).

96 See Copyright Office Strategic Plan, supra note 2, at 43 (referring to "appropriate differentiations between large and small actors" and "appropriate accommodations for small actors").
} 
that Disney Enterprises, Inc. filed over 2300 registration applications in $2015 .^{97}$ Charging a uniform "large entity" fee of, say, $\$ 400$ would potentially burden Disney Enterprises with almost $\$ 1$ million in registration fees, a result that might cause even it to reduce registration activity.

Neel Sukhatme has recently argued that patent fees should be differentiated by the field of technology of the invention. ${ }^{98}$ He notes that owners of patents in some fields of technology have demonstrated that they care more about patent term than owners of patents in other fields. They invested more in obtaining patents quickly when the method of calculating patent term changed to include the time from application to issuance, and they have been renewing at higher rates. ${ }^{99}$ That evidence, he argues, provides a basis for setting patent fees higher for inventions in those fields of technology in which patent term matters more. Copyright fees could similarly be set differently for different types of works of authorship. There are at least two problems with such a proposal, however. First, there is no similar evidence available as to copyright owners' varying sensitivity to copyright term. There has been no change in the method of calculating copyright term that could easily generate evidence as to sensitivity to the length of that term, and the most recent renewal rate information we have is a quarter of a century old, since the copyright renewal requirement was abolished in 1992. Second, the value of works of authorship of a single type likely vary greatly (as do the value of inventions within a single field of technology), and thus setting a single fee for all works in a category would likely make registration prohibitively expensive for owners of some of those works, while getting nowhere near the limit that owners of other works could easily afford.

A third approach, tied neither to the size of the claimant nor the category of work registered, would be to charge tiered registration fees for different statutory damage ceilings, or different packages of registration benefits more generally. Currently, all registered works are eligible for a minimum award of $\$ 750$ in statutory damages, and a maximum of $\$ 30,000$, upon a finding of infringement. ${ }^{100}$ The ceiling is raised to $\$ 150,000$ if the infringement was willful; ${ }^{101}$ the floor is lowered to $\$ 200$ if the infringer "was not aware and had no reason to believe that his or her acts constituted an infringement,"102 and is

${ }^{97}$ See http://cocatalog.loc.gov/ (search for "Disney Enterprises, Inc." as a name, with a search limit of the year 2015, performed on December 23, 2016).

${ }^{98}$ See Neel Sukhatme, Regulatory Monopoly and Differential Pricing in the Market for Patents, 71 Wash. \& Lee L. Rev. 1855 (2014).

${ }^{99}$ See id. at 1900-1908.

${ }^{100}$ See 17 U.S.C. $\$ 504(c)(1)$.

${ }^{101}$ See 17 U.S.C. $\$ 504(\mathrm{c})(2)$.

${ }^{102} \mathrm{Id}$. 
lowered to zero in certain cases involving reasonable beliefs of fair use by nonprofit entities. ${ }^{103}$ However, not every copyright owner is likely to have a strong desire for the possibility of obtaining an award of statutory damages that reaches the current ceilings. Although statutory damages are not dependent on actual damages, they tend to track the likely economic injury to the plaintiff as well as the egregiousness of the defendant's behavior. An infringement of a work such as a stock photograph or a sculpture is unlikely to generate a statutory damages award at the current ceilings, and if a particular infringement turned out to be massive - say, use of stock photograph in an advertising campaign that included billboards around the country and print ads in dozens of major newspapers and magazines - actual damages in the form of a reasonable licensing fee would likely be as large if not larger than a statutory damages award. Some copyright owners also may not be as concerned about infringement. For example, companies may not be particularly worried if commercials for their products are posted on YouTube, thus further promoting their wares; academic authors are usually more concerned about spreading their reputation than monetizing their articles.

Registrants who believe that their works are likely to be of lower value, or who are not particularly interested in protecting the copyright value of their works, could pay substantially less for registration, while receiving a registration with a lower statutory damages ceiling. One could imagine, for example, four tiers of registrations: (1) a registration with a truly nominal fee, say, $\$ 2$, that would afford the holder no statutory damages at all; (2) a registration that cost $\$ 30$, with a statutory damages minimum of $\$ 200$ and a maximum of $\$ 5000$; (3) a registration that cost $\$ 60$, with a statutory damages minimum of $\$ 400$ and a maximum of $\$ 15,000$; and (4) a registration that cost $\$ 120$, with the current statutory damages minimum of $\$ 750$ and maximum. Obviously, it would take further study to set the precise number of tiers, and the fees and minimums and maximums associated with them.

One could conceivably adjust the other benefits of registration as well. For example, the lowest tier of registration might not involve examination of copyrightability by Copyright Office examiners (which would substantially lower the cost of Copyright Office processing); that tier would then not carry with it the presumption that the registered work contained copyrightable subject matter. ${ }^{104}$ However, the question would then arise whether such a registration

\footnotetext{
103 See id.

${ }^{104}$ See 17 U.S.C. $\S 410$ (c) ("In any judicial proceedings the certificate of a registration made before or within five years after first publication of the work shall constitute prima facie evidence of the validity of the copyright ....").
} 
would satisfy $\S 411$ and allow the holder to bring an infringement lawsuit. ${ }^{105}$ Part of the logic of the $\S 411$ requirement of registration as a prerequisite to litigation has been that it serves as a filter, discouraging litigation by those who may not have copyrightable works, and that it provides courts with an expert opinion on copyrightability. ${ }^{106}$ A registration that issued without examination could not perform those functions. The presumption that the facts stated in the registration certificate are true ${ }^{107}$ should probably accompany all levels of registration, since that presumption is probably justified as much by the public airing of those facts in the Copyright Catalog as by any Copyright Office examination of those facts. Whether attorney's fees would be afforded by all registration tiers is also open to question, but insofar as prevailing defendants are always eligible for an award of attorney's fees, under the same standard applied to prevailing plaintiffs who have a timely registration, ${ }^{108}$ providing all registration tiers with the benefit of eligibility for attorney's fees would tend to even the playing field and deter stonewalling by defendants in valid infringement cases. Moreover, stripping away too many benefits could leave copyright owners with too little incentive to register, even with nominal registration fees.

A tiered registration system based on varied limits on statutory damages allows and prompts copyright owners to value their own works, and it is those owners who are probably in the best position to value their works - certainly better than Copyright Office employees. To the extent that tiers of fees based on the size of the entity applying or the category of work have the goal of indirectly detecting the value of the work, tiers of fees based on statutory damages floors and ceilings should much better serve that goal. Tiered fees based on estimated work value have at least three advantages. First, if it is equitable to place a somewhat larger portion of the costs of administering the copyright system on those who own works of higher value, and who therefore benefit more from that system and are in a better position to support it, tiered fees could be an effective means of achieving that equity. Second, tiered registration makes some form of registration affordable for every copyright owner, and would therefore tend to maximize participation in the registration

\footnotetext{
105 See 17 U.S.C. $\$ 411$ (providing that "no civil action for infringement of the copyright in any United States work shall be instituted until preregistration or registration of the copyright claim has been made in accordance with this title").

106 See, e.g., ACCORD Report, supra note 1, Appendix A/52 (Memo from Peter Jaszi to Paul Goldstein, The Case for 411(a), Working Paper \#2a, June 20, 1993) (“"T] he argument for 411(a) is that it is a good thing to have a mechanism by which copyright claims which are to be asserted in litigation are first exposed to some form of administrative scrutiny.").

107 See 17 U.S.C. $\S 410$ (c) ("In any judicial proceedings the certificate of a registration made before or within five years after first publication of the work shall constitute prima facie evidence of the ... facts stated in the certificate.").

108 See Fogerty v. Fantasy, Inc., 510 U.S. 517 (1994).
} 
system, and provide the public with information about the largest possible number of works. Third, if the fees for the tiers are properly adjusted, tiered registration should maximize revenue for the Copyright Office, since owners of works who would not be deterred by paying higher fees would do so, while many of those who would not pay a high fee would still end up paying a lower fee.

To be sure, a tiered registration system with varied statutory damages ceilings also has some disadvantages. First, applied as a one-time front-end choice, it forces copyright owners to value their works in conditions of comparative uncertainty. A system that allowed copyright owners to "buy up" to a higher tier at any time - with the proviso that the higher tier remedies would be applicable only to infringement that commenced after the date of conversion - would reduce that problem. Shifting the recovery of some costs to back-end renewal fees would also help. Second, in deciding what statutory damages ceiling to pay for, a copyright owner may take into account, not only the value of the work, but the likelihood that it will be infringed, and the likelihood that actual damages will be provable. Forcing those whose works are more likely to be infringed, or those who will have a more difficult time proving actual damages, to pay more for registration, may not be desirable. Third, varied statutory damages ceilings may also be attacked as perpetuating and rendering more complex a copyright "caste system," in which more sophisticated, better capitalized applicants get more assistance from courts than individual creators with limited budgets. ${ }^{109}$ Whether that is an entirely fair characterization of the registration system is beyond the scope of this Article, but even if there is a concern about extending additional benefits and remedies to those who participate in the registration system, tiered registration would allow more copyright owners to have at least some of those benefits.

The Copyright Office already has authority to vary registration fees to different applicants, since it is able to set fees that are "fair and equitable and give due consideration to the objectives of the copyright system." 110 However, it cannot currently vary the benefits afforded by registration; those are all uniformly provided by statute. Hence, tiered registration, under which the consequences of registration varied, would require legislation.

\section{SHOUld THE Copyright OfFICE Be SELF-Sustaining?}

\footnotetext{
${ }^{109}$ For an argument that the provision of statutory damages and attorneys' fees upon registration creates such a caste system, see John Tehranian, The Emperor Has No Copyright: Registration, Cultural Hierarchy, and the Myth of American Copyright Militancy, 24 Berkeley Tech. L. J. 1397 (2009); for a similar observation, see Pamela Samuelson \& Tara Wheatland, Statutory Damages in Copyright Law: A Remedy in Need of Reform, 51 Wm. \& Mary L. Rev. 439, 454 (2009).

11017 U.S.C. 708(b)(4).
} 
Before concluding, I want to address directly the issue of whether the Copyright Office should seek to be self-sustaining - an issue that is separate from that of whether it should charge differentiated fees, and which will almost certainly generate more skepticism and opposition in the copyright industries.

The Copyright Office has argued that it is appropriate to set fees to recover only part of the costs of its activities, because "many of the services of the Copyright Office benefit not only individual copyright owners but also the general public, for example, by providing the public with a searchable database of copyright registration and ownership information." 111 Likewise, in its most recent Strategic Plan, it contends that it should receive funding, not only from fees, but from "annual appropriated dollars that reflect the value of its services to entrepreneurs, the public, and the economy." 112 It is difficult to see, however, how in these respects the Copyright Office differs from the Patent and Trademark Office. The PTO also provides searchable databases to the public; its services also have value to entrepreneurs, the public, and the economy; and it also engages in policy research and advising. ${ }^{113}$

Of course, there are some reasons to seek out funding from general appropriations. Since Congress has in fact been willing to appropriate in the range of \$20-\$25 million per year of general taxpayer revenues for the Copyright Office, why would the Office want to end that? Cessation of appropriations from Congress would leave the Office with an absolutely enormous hole to fill, so in the short run, at least, it is much easier to ask Congress for money on the grounds that the Office's operations benefit the public as well as authors and copyright owners. Moreover, when the Copyright Office asks for comments on fee proposals, it receives scores of them, but only from service users who oppose or express concerns about higher fees, arguing that they impose serious burdens. In the most recent fee-setting rulemaking process, the Office received 144 comments, but not a single one came from a taxpayer complaining that her hardearned dollars were being used to subsidize services being provided at belowcost to one particular sector of the economy. ${ }^{114}$ Since the Copyright Office only

\footnotetext{
${ }^{111}$ United States Copyright Office, Proposed Schedule and Analysis of Copyright Fees to Go Into Effect On or About April 1, 2014, at 2, available at https://www.copyright.gov/docs/newfees/USCOFeeStudy-Nov13.pdf.

112 See Copyright Office Strategic Plan, supra note 2, at 42.

113 In Fiscal Year 2016, the Office of Policy and International Affairs of the Patent and Trademark Office has 112 staff members. See PTO FY2016 Report, supra note 58, at 16.

114 The 144 comments received by the Copyright Office in 2012 and 2013 are available at https://www.copyright.gov/docs/newfees/comments/05142012/;

https://www.copyright.gov/docs/newfees/comments/01252013/index.html; and https://www.copyright.gov/docs/newfees/comments/01072012/. The only comments arguing
} 
ever hears comments from one side, ${ }^{115}$ it is no wonder that it pursues a strategy of setting most fees at well below cost and seeking taxpayer appropriations to make up the difference.

It cannot be denied, however, that the strategy of charging below-cost flat fees, and asking Congress to make up the rest, has for decades been able to provide the Copyright Office only with what it itself has called a "shoestring budget," 116 resulting in a raft of service deficiencies. If there is any reason for authors and copyright owners to support a fully fee-funded Copyright Office it is this: A self-sustaining Copyright Office would in the long run be a much healthier, better-functioning, and more stable Copyright Office. That would provide substantial benefits, not just to the general public, but to the copyright industries. Before copyright industry members reject that possibility, they should at least ask themselves whether the self-sustaining PTO provides patent and trademark services, and otherwise supports the patent and trademark systems, in many ways that are better than the Copyright Office currently can for copyright, and whether they cannot imagine Copyright Office improvements that could benefit them substantially.

There are two more reasons why the Copyright Office should perhaps refrain from trying to become fee-funded. First, it is possible that the benefits of copyright registration (and of document recordation) are not sufficiently valuable that registration applicants and document remitters will pay enough for them to support the Office's services and activities. Copyright registration benefits are certainly less valuable than the benefits of obtaining a patent. Without obtaining a patent, an inventor can only protect an invention as a trade secret, and many inventions can be reverse engineered, rendering trade secret protection ineffective. Thus, the value of patent protection can approach the entire value of the invention, while the value of copyright registration never equals the entire value of a work of authorship, since basic copyright protection attaches automatically upon fixation of the work. ${ }^{117}$ However, for those works that retain value over time, the benefits of copyright registration last for the entire copyright term, which is much longer than the term for patents.

that fees were too low came from a group of copyright owners arguing that Licensing Division filing fees for cable systems and satellite operators were being set too low; if those fees are set too low, Licensing Division costs are recovered, not by taxpayers, but by the complaining copyright owners. See, e.g., Comments of the Copyright Owners, available at https://www.copyright.gov/docs/newfees/comments/05142012/Copyright_Owners.pdf.

115 This may be a classic case of concentrated benefits versus diffuse costs. See Mancur Olson, The Logic of Collective Action: Public Goods and the Theory of Groups (1965).

116 See supra note 2.

117 See 17 U.S.C. $§ 102(a)$. 
Copyright registration benefits may also be less valuable than the benefits of registering a trademark. Although federal trademark registration is not necessary for many aspects of protection, it carries such benefits as nationwide protection for a mark; ${ }^{118}$ an opportunity eventually to gain the status of incontestability; ${ }^{119}$ and in the case of intent-to-use registrations, the ability to gain pre-use protection for a mark. ${ }^{120}$ Unlike trademark registration, copyright registration does not increase the geographic area of protection, nor does it enable incontestability or provide for pre-use protection. As explored above, however, copyright registration does afford a number of valuable benefits, including statutory damages and attorney's fees in an infringement suit.

Lastly, one might worry that a fully fee-dependent Copyright Office might act in undesirable ways, either with respect to applications for registration and documents submitted for recordation, or with respect to the policy positions it takes. Michael Frakes and Melissa Wasserman have argued that the PTO's fiscal reliance on post-grant fees have adversely affected its decisionmaking, leading it to be more inclined to grant patents that will generate more post-grant fees, due to maintenance fees and other post-grant charges. ${ }^{121}$ Harold Wegner has argued that the very substantial fees that the PTO receives from requests for continuing examination have skewed its incentives. ${ }^{122}$ Could Copyright Office decisions on registrations be similarly distorted by a differentiated fee structure, particularly one that differentiates over time? At first glance, this seems much less likely, simply because standards of copyrightability are so much lower than standards of patentability, and applications for copyright registration are denied or modified far less frequently than patent applications. ${ }^{123}$ The Copyright Office

${ }^{118}$ See 15 U.S.C. $\S 1057(c)$.

${ }^{119}$ See 15 U.S.C. $\$ 1065$.

${ }^{120}$ See 15 U.S.C. $\$ 1051(\mathrm{~b})$.

121 See Michael D. Frakes \& Melissa F. Wasserman, Does Agency Funding Affect Decisionmaking?: An Empirical Assessment of the PTO's Granting Patterns, 66 Vand. L. Rev. 67 (2013).

${ }^{122}$ See Harold C. Wegner, The RCE Innovation Tax on the Inventive Community: Fostering or Discouraging Innovation? (2017), available at http://www.laipla.net/wpcontent/uploads/2017/01/RCEPaperJan4_2017.pdf.

${ }^{123}$ Although everyone anecdotally knows that this is true, there are unfortunately no readily available statistics on Copyright Office registration denials. While the PTO's patent and trademark catalogs contain information on patent applications and trademark registration applications that have been denied, the Copyright Office Catalog only contains information on granted registrations. Moreover, the Copyright Office does not even publish the opinions that its Copyright Board of Appeals issues on appeals from registration denials. An incomplete set of those opinions has been made available by the University of New Hampshire School of Law, which had to file a Freedom of Information Act request to obtain them. See https://ipmall.law.unh.edu/content/us-copyright-office-board-appeals-decisions (home page for the collection of decisions); https://library.law.unh.edu/node/590 (discussing the FOIA request). Transparency could be greatly improved in this area. 
has very little room to increase the percentage of registration applications it grants, and would not gain much additional revenue by granting every last application it received. Thus, although grant patterns should be monitored for possible distortions, the somewhat remote potential for such distortions should not be a reason to refrain from considering back-end registration fees.

Would a self-sustaining, fee-funded Copyright Office likely take different positions on copyright policy issues, because it would be more beholden to the users that are paying the fees, in the way that a nonprofit organization might be beholden to the donors that support it? This also seems unlikely. The fees that the Copyright Office charges are for services and rights that have their own intrinsic value, independent of any policy advice the Office might or might not give. Copyright owners value the presumption of validity that a certificate of registration gives, and the statutory damages and attorney's fees that registration affords in case of infringement, and the legal protections provided by recording documents. Thus, they will keep registering works and recording documents regardless of whether they approve of the policy advice that the Copyright Office gives. Of course, the Office does have a financial interest in aspects of registration and recordation policy that affect its revenues from those activities, and its policy recommendations in those areas should perhaps be more closely scrutinized. However, the Office already has a major stake in registration and recordation when over half of its budget comes from fees for those services, and it is already difficult for its advice to be impartial; little changes in that regard if the Office becomes wholly supported by those fees.

None of this is to say that that Congress should cut off appropriations to the Copyright Office tomorrow, and force it to raise its entire budget from fees. As noted above, the Copyright Office could almost certainly not become selfsufficient without revenue from some sort of registration renewal fees, just as the PTO is dependent on patent maintenance fees and trademark registration renewal fees. Yet if the Copyright Office created a renewal registration system tomorrow, it could likely do so only prospectively, which means that renewal revenues would only start to appear when the initial registration period was over, most likely a decade or more from now. Moreover, decades of underfunding mean that the Copyright Office needs a great deal of money just to catch up to the twenty-first century. In its 2016 Provisional Information Technology Plan, the Copyright Office has estimated that it would need about $\$ 165$ million over the next five years to modernize its IT infrastructure ${ }^{124}$ - about $\$ 33$ million per year above and beyond its normal budget. The Office would have a much harder

${ }^{124}$ See United States Copyright Office, Provisional Information Technology Modernization Plan and Cost Analysis, supra note 15, at 2. 
time raising that level of funding from fees, and should not be expected to. Thus, the goal of self-sufficiency is a long-term goal only, and appropriations, even increased appropriations, would be needed in the meantime.

\section{CONCLUSION}

The Copyright Office has suffered for decades from underfunding, as it has depended on a combination of essentially flat, front-end fees and supplementary Congressional appropriations to meet its budget needs. As a result, it has been unable fully perform its functions, in spite of laudable efforts to do as much as it can with its limited resources. Congress should consider authorizing the Copyright Office to charge differentiated fees for its services, both across time through creation of registration renewal requirements, and between different works and registrants. Congress should also consider authorizing the Copyright Office to set fees at rates sufficient to cover all of its costs, not just the costs of the services it provides, and to cover the costs of both current operations and capital improvements. The Copyright Office should also be able to fund a reserve account, enabling it to continue operations and investment in capital improvements even in case of emergencies or temporary shortfalls in fee collections. Because some new fees would only start to generate income in many years, and because the Copyright Office has fallen far behind due to past underfunding, Congress should for the time being continue to provide appropriated funds to the Office, and should in fact substantially increase funding. Yet the benefits of self-funding are substantial enough that the Copyright Office should begin to move in that direction, whether or not it is

eventually able to attain that goal, and whether it remains in the Library of Congress, becomes independent, or finds some other institutional home. 